Article

\title{
RT-qPCR Analysis of 15 Genes Encoding Putative Surface Proteins Involved in Adherence of Listeria monocytogenes
}

\author{
Hung King Tiong ${ }^{1,2}$ and Peter M. Muriana ${ }^{1,2, *}$ \\ 1 Department of Animal Science, Monroe Street, Oklahoma State University, Stillwater, OK 74078, USA; \\ htiong@ostatemail.okstate.edu \\ 2 Robert M. Kerr Food \& Agricultural Products Centre, 109 FAPC Building, Monroe Street, \\ Oklahoma State University, Stillwater, OK 74078-6055, USA \\ * Correspondence: peter.muriana@okstate.edu; Tel.: +1-405-744-5563; Fax: +1-405-744-6313
}

Academic Editors: Alexandru Mihai Grumezescu and Alina Maria Holban

Received: 27 July 2016; Accepted: 28 September 2016; Published: 1 October 2016

\begin{abstract}
L. monocytogenes adherence to food-associated abiotic surfaces and the development of biofilms as one of the underlying reasons for the contamination of ready-to-eat products is well known. The over-expression of internalins that improves adherence has been noted in cells growing as attached cells or at elevated incubation temperatures. However, the role of other internalin-independent surface proteins as adhesins has been uncharacterized to date. Using two strains each of weaklyand strongly-adherent L. monocytogenes as platforms for temperature-dependent adherence assays and targeted mRNA analyses, these observations (i.e., sessile- and/or temperature-dependent gene expression) were further investigated. Microplate fluorescence assays of both surface-adherent strains exhibited significant $(P<0.05)$ adherence at higher incubation temperature $\left(42^{\circ} \mathrm{C}\right)$. Of the 15 genes selected for RT-qPCR, at least ten gene transcripts recovered from cells (weakly-adherent strain CW35, strongly-adherent strain 99-38) subject to various growth conditions were over expressed [planktonic $/ 30{ }^{\circ} \mathrm{C}(10)$, sessile $/ 30^{\circ} \mathrm{C}(12)$, planktonic $/ 42{ }^{\circ} \mathrm{C}(10)$ ] compared to their internal control (16SrRNA transcripts). Of four genes overexpressed in all three conditions tested, three and one were implicated as virulence factors and unknown function, respectively. PCR analysis of six unexpressed genes revealed that CW35 possessed an altered genome. The results suggest the presence of other internalin-independent adhesins (induced by growth temperature and/or substratum) and that a group of suspect protein members are worthy of further analysis for their potential role as surface adhesins. Analysis of the molecular basis of adherence properties of isolates of L. monocytogenes from food-associated facilities may help identify sanitation regimens to prevent cell attachment and biofilm formation on abiotic surfaces that could play a role in reducing foodborne illness resulting from Listeria biofilms.
\end{abstract}

Keywords: L. monocytogenes; adherence; biofilm; expression; surface proteins

\section{Introduction}

L. monocytogenes is a Gram-positive, intracellular foodborne human pathogen, capable of surviving antimicrobial hurdles such as limited oxygen [1], degenerative agents associated with immunological response (phagocytosis) [2], bile salts $(10 \%)$ [3], and extreme temperatures $\left(-0.4-50{ }^{\circ} \mathrm{C}\right)$ [3]. The systemic disease it causes is termed listeriosis and it has a multitude of diagnostic manifestations such as miscarriage, muscle pain, stillbirth [4], meningitis [5], septicemia [2], pneumonia [6], corneal ulcers [7], fever, and gastroenteritis [8] in patients. In large outbreaks it has among the highest mortality rates $(20 \%-25 \%)$ as compared to other foodborne pathogens reported by the Centers for Disease 
Control and Prevention [9]. These stress tolerant characteristics have been linked to the pathogen's molecular defense mechanisms contributed by proteins with essential roles such as biofilm-associated protein (BapL) [10], general stress-response regulation by sigma factor B (SigB), membrane lysis by Listeriolysin $\mathrm{O}$ (Hly), and phospholipase during phagocytosis for cell sustainability/viability to intracellular stresses [2]. Other Listeria virulence factors include adhesins for attachment and invasins to gain entry into host cells (InlA, lmo0433; InlB, lmo0434; Vip, lmo0320; Ctap, lmo0135; FbpA, lmo1829; IspC; Ami, lmo2558; LapB, lmo1666; Iap 60, lmo0582) and cell-to-cell movement mediated by the polymerization of actin (ActA, lmo0204) [2].

Persistence of this bacterium in food products manufactured under standard sanitation protocols, especially with ready-to-eat (RTE) processed foods such as dairy products, meats, vegetables, and fish [11,12] are generally caused by cross-contamination of foods contacting L. monocytogenes-contaminated surfaces. Biofilm formation following initial adherence increases the cell's resistance to elimination and removal by current sanitation regimens [13-16]. Isolates of L. monocytogenes from raw and processed meats and food processing facilities are capable of adhering to numerous substrate surfaces such as stainless steel, polystyrene, rubber, plastic, and glass, and different strains display different degrees of adherence $[17,18]$. They also demonstrated that although the weak and strongly-adherent variants adhered equally well to biotic cells, the strongly-adherent strains were more invasive as demonstrated in virulence assays in Caco-2 tissue culture and live mouse assays $[19,20]$. Studies by other investigators have demonstrated that adherence strength may be correlated to incubation temperature [3,21]. To date, four surface-associated adhesins, including inlA, inlB, bap L, and the Staphylococcus epidermidis ami homolog atl (lmo2558), have been characterized by different groups for attachment to abiotic surfaces $[10,22,23]$. However, single mutants (inlA, inlB, bap $\mathrm{L}$, ami) or double deletions (inl $\mathrm{A}$ and inlB) did not abolish abiotic attachment completely suggesting that adherence is mediated by multiple loci or factors.

The purpose of this study was to examine the expression of surface-associated proteins that were previously implicated as potential candidates for involvement with surface adherence based on comparative MS-LC/MS analyses of different phenotypic strains and growth conditions. Insights on attachment mechansims may provide for more effective sanitation of food processing facilities. In this study, mRNA levels of gene transcription were evaluated for 15 genes encoding cell surface proteins identified previously as potentially involved with attachment to abiotic surfaces [24]. These results are compared to those of Chen et al. [25] who evaluated two genes, inlA and inlB to establish positive correlations between gene expression and attachment strength of two adherent phenotypes of L. monocytogenes. Gene targets were determined based on multiple LC-MS/MS comparative analyses of surface sub-proteome extracts of adherence variants of L. monocytogenes (CW35/weak vs. 99-38/strong) [24]. A group of 15 genes, including a 16S rRNA reference gene [26], inlA [25], and 14 other target genes suggested in LC-MS/MS data were utilized for this purpose [24].

\section{Results}

\subsection{Adherence Properties of Various Strains of L. monocytogenes}

In the current study, a group of 15 test genes implicated in LC-MS/MS analyses of surface sub-proteomes of L. monocytogenes as suspect adhesins were derived from (two each) strongly- and weakly-adherent phenotypic groups of L. monocytogenes; the strains used in the current study were from the same L. monocytogenes food isolates (i.e., CW35 and 99-38) used in a prior LC-MS/MS study [24]. Using a fluorescent microplate adherence assay [18] (Table 1) eight previously characterized strains of L. monocytogenes were confirmed as belonging to two distinct adherence groups of $L$. monocytogenes (Figures 1 and 2). Strongly-adherent strains (CW50, CW62, CW77, 99-38) gave greater than 10-fold higher RFU signals than weakly-adherent strains (CW34, CW35, CW52, CW72) in the microplate adherence assay, agreeing with previous published findings [17-19]. 
Gorski noted that L. monocytogenes cells exhibited increased adherence to vegetative surfaces when higher incubation temperatures were used [3]. This observation was consistent with the results in the microplate adherence assays whereby both adherence phenotypes of Listeria revealed higher adherence at $42{ }^{\circ} \mathrm{C}$ incubation temperature than at $30{ }^{\circ} \mathrm{C}$. The findings suggest that temperature may be an important factor impacting adherence of L. monocytogenes in food manufacturing facilities (Figure 3) [3].

Morange et al. [27] and Kushwaha and Muriana [19] further reported that the virulence (i.e., invasiveness) of L. monocytogenes was dependent upon incubation temperature and the strong adherence phenotype in L. monocytogenes, respectively, and possibly suggesting a correlation between virulence and adherence factors. In regards to food processing, higher temperatures resulting in greater levels of adherence could correlate to a greater degree of equipment surface contamination and food product contamination.

Table 1. Strains of L. monocytogenes used in this study.

\begin{tabular}{|c|c|c|c|c|}
\hline Strain ${ }^{a}$ & Serotype & Adherence phenotype ${ }^{b}$ & Origin of isolation & Reference \\
\hline CW34 & $\mathrm{ND}^{\mathrm{c}}$ & Weak & RTE retail frankfurters & {$[9,18,19]$} \\
\hline CW35 & $\mathrm{ND}^{\mathrm{c}}$ & Weak & RTE retail frankfurters & {$[9,18,19]$} \\
\hline CW50 & $\mathrm{ND}^{\mathrm{c}}$ & Strong & RTE retail frankfurters & {$[9,18,19]$} \\
\hline CW52 & $\mathrm{ND}^{\mathrm{c}}$ & Weak & RTE retail frankfurters & {$[9,18,19]$} \\
\hline CW62 & $\mathrm{ND}^{\mathrm{c}}$ & Strong & RTE retail frankfurters & {$[9,18,19]$} \\
\hline CW72 & $\mathrm{ND}^{\mathrm{c}}$ & Weak & RTE retail frankfurters & {$[9,18,19]$} \\
\hline CW77 & $\mathrm{ND}^{\mathrm{c}}$ & Strong & RTE retail frankfurters & {$[9,18,19]$} \\
\hline EGDe & $1 / 2 \mathrm{a}$ & Strong & Animal (EGD derivative) & [28] \\
\hline Jag167 & $\mathrm{ND}^{\mathrm{c}}$ & Strong & RTE meat processing facilities & [17] \\
\hline $99-38$ & $\mathrm{ND}^{\mathrm{c}}$ & Strong & Retail ground beef & {$[18,19]$} \\
\hline
\end{tabular}

${ }^{\text {a }}$ L. monocytogenes strains $99-38, \mathrm{CW}$ and Jag were isolates from our collection; ${ }^{\mathrm{b}}$ Determined by microplate adherence assay $[18]{ }^{\mathrm{c}} \mathrm{ND}$, not determined.

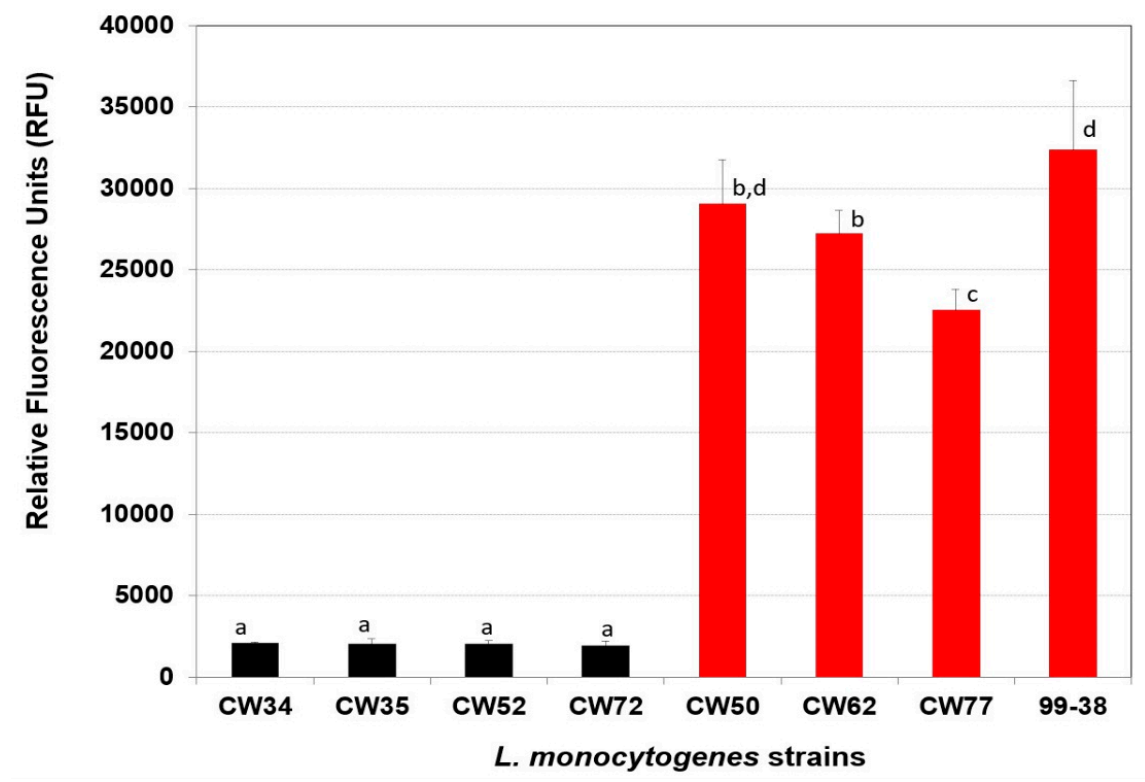

Figure 1. Adherence of various strains of L. monocytogenes using the microplate fluorescence (5,6-CFDA) adherence assay. Weakly- and strongly-adherent strains are represented by black and red bars, respectively. Data bars represent the mean of triplicate replications. Means that share the same lowercase letters are not significantly different; means with different letters are significantly different $(P<0.05)$. The error bars indicate standard deviation from the mean. 


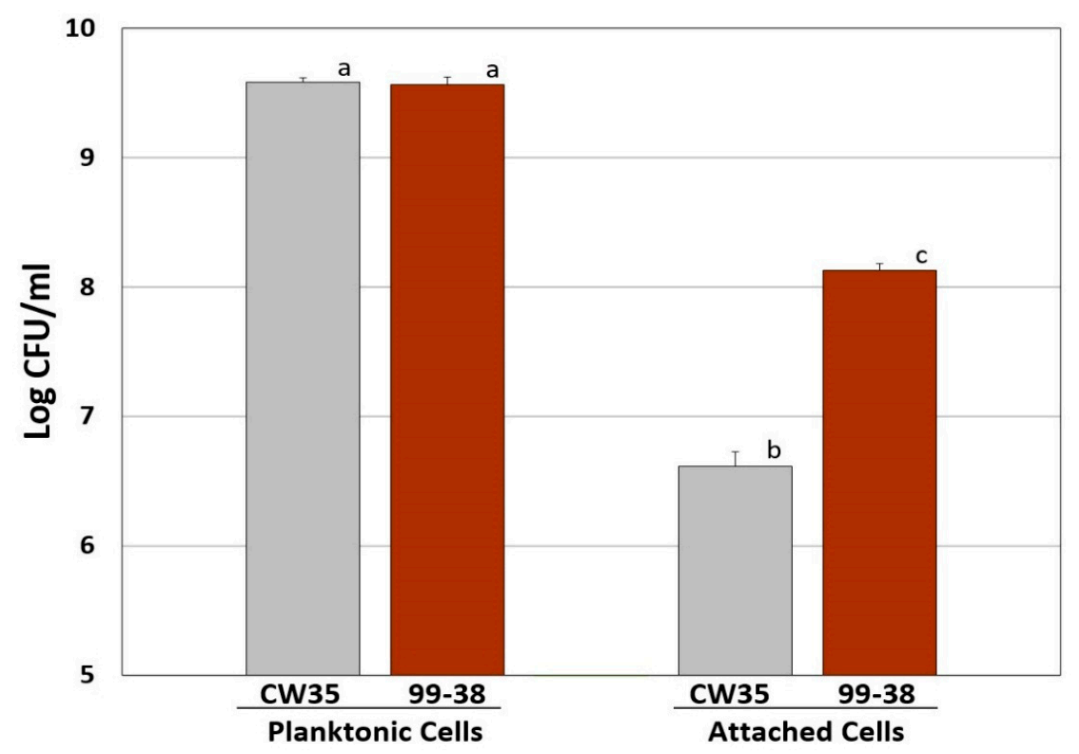

Figure 2. Comparison of attachment characteristics of L. monocytogenes CW35 (weakly-adherent) and 99-38 (strongly-adherent) in microplate wells. Enumeration of well cell cultures (left) and attached cells (right) after release by treatment with protease. All data represent the means of triplicate replications. Means with the same lowercase letters are not significantly different; means with different letters are significantly different $(P<0.05)$. Error bars indicate standard deviation from the mean. CFU, colony forming units.

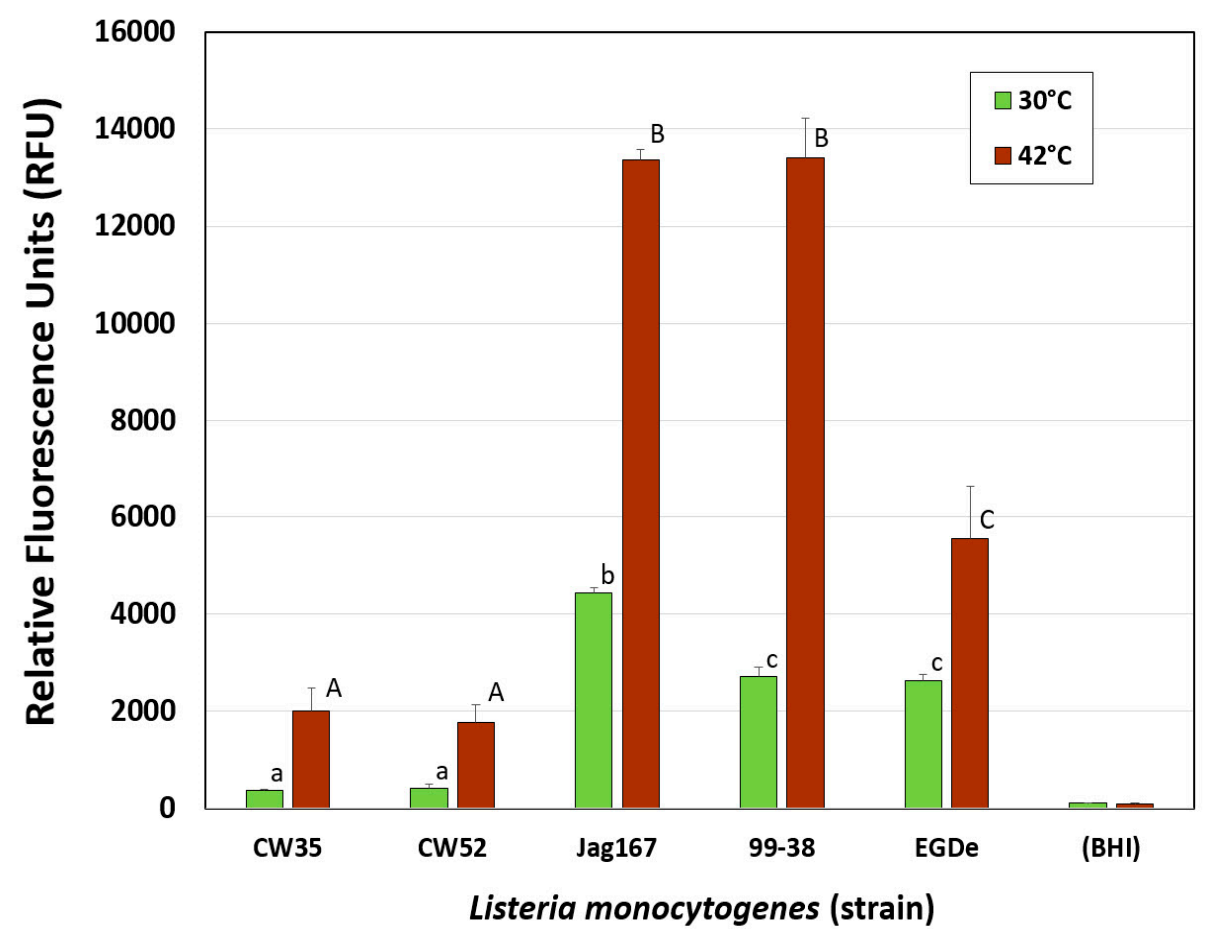

Figure 3. Effect of temperature $\left(30^{\circ} \mathrm{C}\right.$ vs. $\left.42{ }^{\circ} \mathrm{C}\right)$ on attachment of different adherence-variant strains of L. monocytogenes (strongly adherent: Jag167, 99-38, EGDe; weakly adherent: CW35, CW52) as determined by the microplate adherence assay. Uninoculated brain heart infusion (BHI) nutrient broth was tested as a control. All data represent the means of triplicate replications. Means with the same upper/lowercase letters are not significantly different; means with different upper/lower case letters are significantly different $(P<0.05)$. Error bars indicate standard deviation from the mean. RFU, relative fluorescence units. 


\subsection{Differential Gene Expression of Two Adherence-Variant Strains of L. monocytogenes}

A subset of transcripts of L. monocytogenes total RNA from weakly (CW35) and strongly (99-38) adherent phenotypes, recovered from various growth conditions such as sessile (bead attached cells) or planktonic at $42{ }^{\circ} \mathrm{C}$ or $30^{\circ} \mathrm{C}$ (control), was quantitated using RT-qPCR relative to $16 \mathrm{~S}$ rRNA. Strains of L. monocytogenes were initially selected based on involvement with either raw or processed meat production since both use raw meat ingredients from similar sources. Subsequent selectivity of strains was based on adherence characteristics as determined by microplate adherence assay for further analysis in the current study (Figure 1). Growth conditions were adapted from Hong et al. [29] and McGann et al. [21] for the reason that the beads used for sessile cells preparation rendered more surface area of growth than a 96-well microplate. In addition, the incubation temperature $\left(42{ }^{\circ} \mathrm{C}\right)$ was the highest temperature used that rendered significant differential expression of the surface adhesins corresponding genes, inlA and inlB. Relative transcripts of both strains were obtained using a relative expression quantification method for analysis of data containing inconsistent amplification efficiencies [30] (Table 2) and the normalized data was plotted in Figure 4. Overexpressed genes (expression $\geq 2$-fold or detected only in a single strain) were primarily attained in 99-38 cells recovered from planktonic at $30{ }^{\circ} \mathrm{C}\left(7\right.$ overexpressed in 99-38 vs. 3 in CW35) and $42{ }^{\circ} \mathrm{C}$ (7 in 99-38 vs. 3 in CW35), and from sessile cells at $30^{\circ} \mathrm{C}$ (10 in 99-38 vs. 2 in CW35) (Table 3). On the other hand, four overexpressed genes (lmo0202, lmo1293, lmo2505, lmo2656) from both CW35 and 99-38 strains were detected at either elevated temperature $\left(42^{\circ} \mathrm{C}\right)$ or during sessile conditions (Table 4$)$.

Nightingale [31], and Chen et al. [25] reported that truncated forms of inlA/B are common among L. monocytogenes food isolates. Similarly, we observed that CW35 chromosomal DNA possessed an altered form of $i n l \mathrm{~A}$ gene (3-codon deletion detected in the $\mathrm{C}$-terminus) and thus producing truncated form of InlA protein in all conditions tested relative to 16S rRNA mRNA levels (data not shown).

In addition to expression variations caused by the external factors, the gene of interest might have mutations at their primer-binding regions, which could reduce the PCR amplification efficiency of that gene in comparison to other strains, and hence cause false expression levels [32]. As demonstrated in Table 5, the amplification efficiencies of each gene varied among strains tested (Table 6) and these amplification differences were corrected thereby validating our expression data [30,33-35]. 


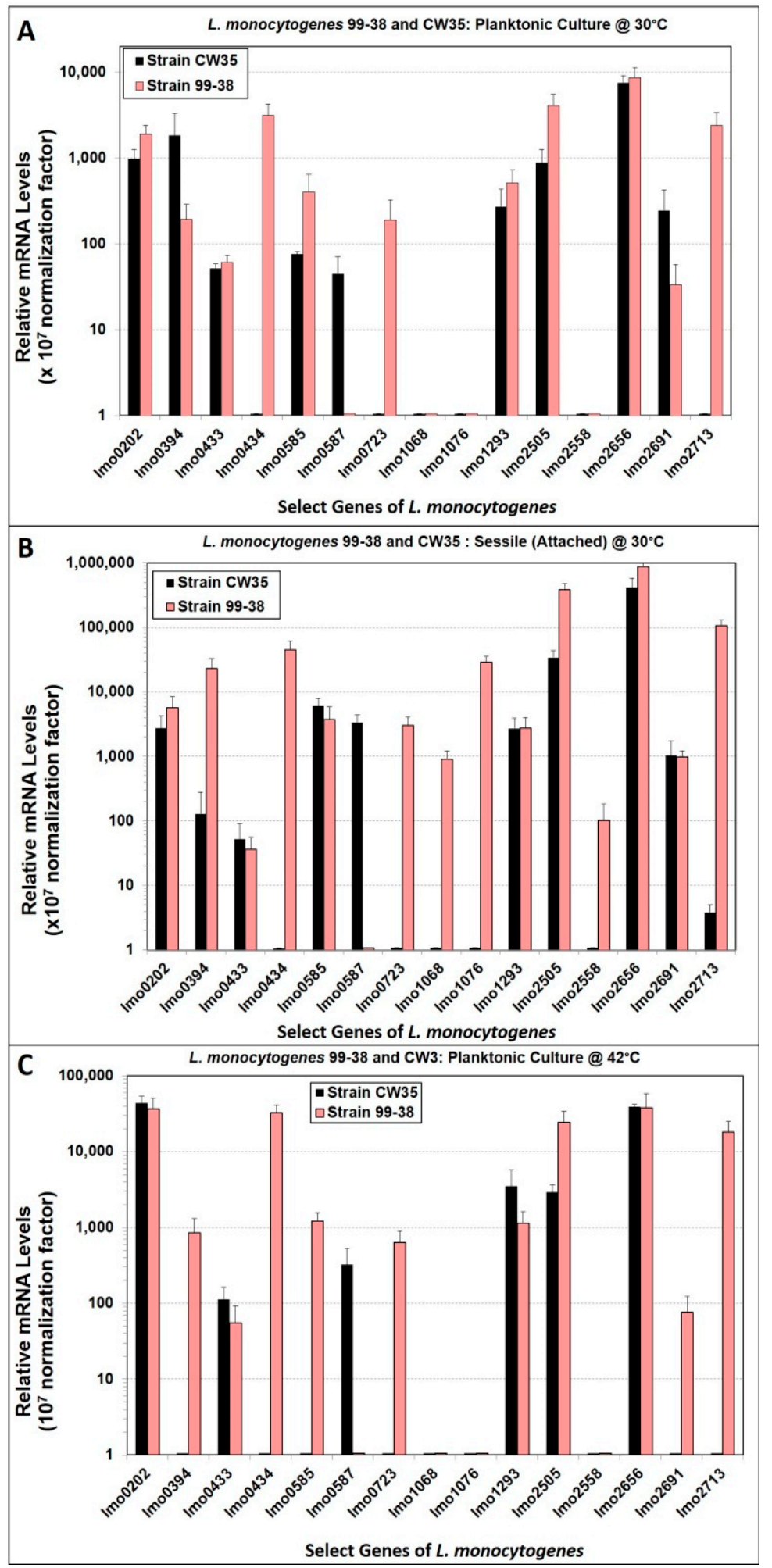

Figure 4. Relative transcript expression profiles of select genes from weakly-adherent (CW35) and strongly-adherent (99-38) strains of L. monocytogenes. Panel A, from cells recovered from planktonic growth at $30{ }^{\circ} \mathrm{C}$. Panel $\mathrm{B}$, from cells attached to glass beads during growth at $30{ }^{\circ} \mathrm{C}$. Panel $\mathrm{C}$, from planktonic cells grown at $42{ }^{\circ} \mathrm{C}$. Expression is relative to that of the reference gene, $16 \mathrm{~S}$ rRNA. All data bars represent the means of triplicate replications for gene expression RT-qPCR assays. Error bars indicate the standard deviation from the mean. Expression was normalized $\left(\times 10^{7}\right.$ factor $)$ to eliminate negative expression levels. 


\subsection{PCR Amplification of Genes}

Of six genes with no detectable mRNA levels, two genes (lmo1076, lmo2558) have been reportedly absent in both L. monocytogenes serotypes $4 \mathrm{a}$ and $4 \mathrm{~b}$ strains (Tables 2-4) [2]. PCR analysis of these genes in CW35, 99-38, and EGDe (type strain) genomes with the gene specific primers listed in Table 6, revealed normal (lmo0434, lmo0587; lmo0723, Figure 5) and altered (lmo1068, lmo1076, lmo2558; Figure 5) gene sequences based on expected amplimer size. All altered non-lethal genes were only observed in the CW35 strain. Further PCR analysis of altered genes with different primers (Table 6) suggested that the alteration was due to a deletion (lmo1076) and nucleotide alterations (lmo1068, lmo2558) (data not shown), suggesting that CW35 strain possesses altered lmo1068, lmo1076, and $1 \mathrm{mo} 2558$ genes that may affect adherence. Thus, alterations observed with $1 \mathrm{mo1076}$ and $1 \mathrm{mo} 2558$ agree with the results reported by Camejo et al. [2].

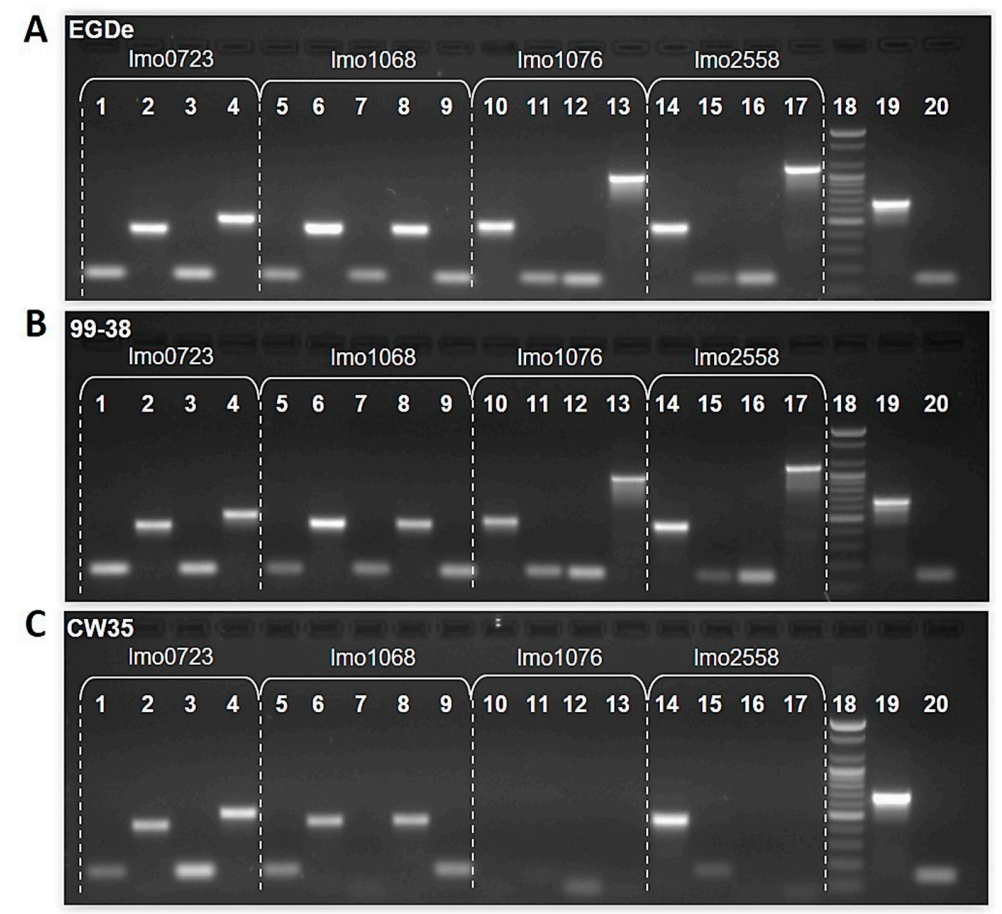

Figure 5. PCR products from genomic DNA of L. monocytogenes EDGe (Panel A), 99-38 (Panel B), and CW35 (Panel C) for PCR nucleotide evaluation of 1mo0723, lmo1068, lmo1076, and lmo2558. Different gene-specific primer pairs were used for PCR amplification and subsequent agarose gel analysis of products. PCR primer combinations were based on L. monocytogenes type strain EGDe (Panel A) and tested on 99-38 (Panel B) and CW35 (Panel C). Gene lmo0723 : Lane 1, 0723A (148bp); 2, 0723B (416bp); 3, 0723C (150bp); 4, 0723D (505bp); 1mo1068 : 5, 1068A (149bp); 6, 1068B (438bp); 7, 1068C (149bp); 8, 1068D (440bp); 9, 1068E (147bp); lmo1076 : 10, 1076A (470bp); 11, 1076B (150bp); 12, 1076C (146bp); 13, 1076D (991bp); lmo2558 : 14, 2558A (458bp); 15, 2558B (148bp); 16, 2558C (149bp); 17, 2558D (1129bp); 18, 100bp DNA ladder; 19 and 20, positive controls.

\subsection{The Function and Virulence Information of Overexpressed Genes of L. monocytogenes}

The functions of five genes (of the 15 genes examined) were determined by using Leger [36] and ListiList [37] post-genome database for Listeria research and functional classification tools, respectively, as their functions are currently unrevealed [2,38]. They were secreted proteins (2), ribosomal protein S12-like protein (1), methyl-accepting chemotaxis-like protein (1), and unknown protein (1) (Table 7). Of the ten remaining genes studied, seven have been experimentally characterized as virulence (6) and non-virulence (1; lmo2713) [39] factors, whereas two were Iap-like proteins (lmo0394, lmo2505), Listeria virulence factor [40], and one was not virulence-related as implicated in intracellular down regulation (lmo2691) [41]. 
Table 2. Relative mRNA levels of 15 genes as compared to the reference gene (i.e., $16 \mathrm{~S}$ rRNA gene).

\begin{tabular}{|c|c|c|c|c|c|c|}
\hline \multirow{2}{*}{ Gene Name } & \multicolumn{3}{|l|}{ L. monocytogenes CW35 } & \multicolumn{3}{|l|}{ L. monocytogenes 99-38 } \\
\hline & Bead-sessile $+30^{\circ} \mathrm{C}^{\mathrm{a}}$ & Planktonic $+30^{\circ} \mathrm{C}^{\mathrm{a}}$ & Planktonic $+42{ }^{\circ} \mathrm{C}^{\mathrm{a}}$ & Bead-sessile $+30^{\circ} \mathrm{C}^{\mathrm{a}}$ & Planktonic $+30^{\circ} \mathrm{C}^{\mathrm{a}}$ & Planktonic $+42{ }^{\circ} \mathrm{C}^{\mathrm{a}}$ \\
\hline $\operatorname{lmo} 0202$ & 2.7E-04 (1.5E-04) & 9.7E-05 (2.7E-05) & $4.4 \mathrm{E}-03$ (9.5E-04) & 5.7E-04 (2.7E-04) & $1.9 \mathrm{E}-04(4.9 \mathrm{E}-05)$ & 3.6E-03 (1.5E-03) \\
\hline $\operatorname{lmo0394}$ & $1.3 \mathrm{E}-05$ (1.5E-05) & $1.8 \mathrm{E}-04(1.5 \mathrm{E}-04)$ & $0.0 \mathrm{E}+00(0.0 \mathrm{E}+00)$ & $2.3 \mathrm{E}-03(1.0 \mathrm{E}-03)$ & $1.9 \mathrm{E}-05$ (9.7E-06) & $8.5 \mathrm{E}-05$ (4.7E-05) \\
\hline $\operatorname{lmo} 0433$ & $5.2 \mathrm{E}-06(3.8 \mathrm{E}-06)$ & $5.2 \mathrm{E}-06$ (7.0E-07) & $1.1 \mathrm{E}-05(5.0 \mathrm{E}-06)$ & $3.6 \mathrm{E}-06(1.9 \mathrm{E}-06)$ & $6.1 \mathrm{E}-06$ (1.3E-06) & $5.6 \mathrm{E}-06(3.6 \mathrm{E}-06)$ \\
\hline $\operatorname{lmo} 0434$ & $0.0 \mathrm{E}+00(0.0 \mathrm{E}+00)$ & $0.0 \mathrm{E}+00(0.0 \mathrm{E}+00)$ & $0.0 \mathrm{E}+00(0.0 \mathrm{E}+00)$ & $4.5 \mathrm{E}-03(1.7 \mathrm{E}-03)$ & $3.1 \mathrm{E}-04(1.1 \mathrm{E}-04)$ & $3.3 \mathrm{E}-03(8.7 \mathrm{E}-04)$ \\
\hline $\operatorname{lmo} 0585$ & $6.00 \mathrm{E}-04(1.94 \mathrm{E}-04)$ & $7.59 \mathrm{E}-06$ (4.86E-07) & $0.00 \mathrm{E}+00(0.00 \mathrm{E}+00)$ & $3.73 \mathrm{E}-04(2.07 \mathrm{E}-04)$ & $4.04 \mathrm{E}-05(2.42 \mathrm{E}-05)$ & $1.21 \mathrm{E}-04(3.57 \mathrm{E}-05)$ \\
\hline $\operatorname{lmo} 0587$ & 3.3E-04 (1.0E-04) & $4.5 \mathrm{E}-06(2.6 \mathrm{E}-06)$ & $3.3 \mathrm{E}-05(2.0 \mathrm{E}-05)$ & $0.0 \mathrm{E}+00(0.0 \mathrm{E}+00)$ & $0.0 \mathrm{E}+00(0.0 \mathrm{E}+00)$ & $0.0 \mathrm{E}+00(0.0 \mathrm{E}+00)$ \\
\hline $\operatorname{lmo} 0723$ & $0.0 \mathrm{E}+00(0.0 \mathrm{E}+00)$ & $0.0 \mathrm{E}+00(0.0 \mathrm{E}+00)$ & $0.0 \mathrm{E}+00(0.0 \mathrm{E}+00)$ & $3.0 \mathrm{E}-04(1.1 \mathrm{E}-04)$ & $1.9 \mathrm{E}-05$ (1.3E-05) & $6.3 \mathrm{E}-05(2.7 \mathrm{E}-05)$ \\
\hline $\operatorname{lmo} 1068$ & $0.0 \mathrm{E}+00(0.0 \mathrm{E}+00)$ & $0.0 \mathrm{E}+00(0.0 \mathrm{E}+00)$ & $0.0 \mathrm{E}+00(0.0 \mathrm{E}+00)$ & $9.1 \mathrm{E}-05$ (2.9E-05) & $0.0 \mathrm{E}+00(0.0 \mathrm{E}+00)$ & $0.0 \mathrm{E}+00(0.0 \mathrm{E}+00)$ \\
\hline $\operatorname{lmo1076}$ & $0.0 \mathrm{E}+00(0.0 \mathrm{E}+00)$ & $0.0 \mathrm{E}+00(0.0 \mathrm{E}+00)$ & $0.0 \mathrm{E}+00(0.0 \mathrm{E}+00)$ & $2.9 \mathrm{E}-03(5.9 \mathrm{E}-04)$ & $0.0 \mathrm{E}+00(0.0 \mathrm{E}+00)$ & $0.0 \mathrm{E}+00(0.0 \mathrm{E}+00)$ \\
\hline $\operatorname{lmo1293}$ & 2.7E-04 (1.2E-04) & 2.7E-05 (1.6E-05) & 3.5E-04 (2.3E-04) & $2.8 \mathrm{E}-04$ (1.2E-04) & $5.2 \mathrm{E}-05(2.1 \mathrm{E}-05)$ & $1.1 \mathrm{E}-04$ (4.7E-05) \\
\hline $\operatorname{lmo} 2505$ & $3.4 \mathrm{E}-03$ (1.0E-04) & 8.8E-05 (3.8E-05) & 2.9E-04 (7.6E-05) & $3.8 \mathrm{E}-02(1.9 \mathrm{E}-04)$ & $4.1 \mathrm{E}-04(1.5 \mathrm{E}-04)$ & $2.5 \mathrm{E}-03(9.4 \mathrm{E}-04)$ \\
\hline $\operatorname{lmo} 2558$ & $0.0 \mathrm{E}+00(0.0 \mathrm{E}+00)$ & $0.0 \mathrm{E}+00(0.0 \mathrm{E}+00)$ & $0.0 \mathrm{E}+00(0.0 \mathrm{E}+00)$ & $1.0 \mathrm{E}-05(8.1 \mathrm{E}-06)$ & $0.0 \mathrm{E}+00(0.0 \mathrm{E}+00)$ & $0.0 \mathrm{E}+00(0.0 \mathrm{E}+00)$ \\
\hline $\operatorname{lmo} 2656$ & 4.1E-02 (1.7E-02) & $7.5 \mathrm{E}-04(1.6 \mathrm{E}-04)$ & 3.9E-03 (3.3E-04) & 8.7E-02 (2.6E-02) & 8.6E-04 (2.7E-04) & $3.8 \mathrm{E}-03(2.1 \mathrm{E}-03)$ \\
\hline $\operatorname{lmo} 2691$ & $1.0 \mathrm{E}-04(7.2 \mathrm{E}-05)$ & 2.5E-05 (1.8E-05) & $0.0 \mathrm{E}+00(0.0 \mathrm{E}+00)$ & 9.7E-05 (2.4E-05) & 3.3E-06 (2.5E-06) & 7.7E-06 (4.6E-06) \\
\hline $\operatorname{lmo} 2713$ & $3.8 \mathrm{E}-07$ (1.2E-07) & $0.0 \mathrm{E}+00(0.0 \mathrm{E}+00)$ & $0.0 \mathrm{E}+00(0.0 \mathrm{E}+00)$ & $1.1 \mathrm{E}-02(2.3 \mathrm{E}-03)$ & $2.4 \mathrm{E}-04(9.9 \mathrm{E}-05)$ & $1.8 \mathrm{E}-03(6.6 \mathrm{E}-04)$ \\
\hline
\end{tabular}

${ }^{a}$ Expression data represents an average of 2 technical replicates for each of 3 biological replicates with the standard deviation of the mean given in parenthesis. 
Table 3. Select transcriptional expression comparisons (fold-differences) of L. monocytogenes 99-38 and CW35 cells under different conditions.

\begin{tabular}{|c|c|c|c|c|c|c|}
\hline \multirow[t]{2}{*}{ Locus Tag } & \multicolumn{2}{|c|}{ Planktonic $\left(30^{\circ} \mathrm{C}\right)$} & \multicolumn{2}{|c|}{ Sessile $\left(30^{\circ} \mathrm{C}\right)$} & \multicolumn{2}{|c|}{ Planktonic $\left(42^{\circ} \mathrm{C}\right)$} \\
\hline & 99-38 & CW35 & $99-38$ & CW35 & $99-38$ & CW35 \\
\hline $\operatorname{lmo} 0202$ & $\overline{1.95}$ & - & $\overline{2.1}$ & - & $\overline{-}$ & - \\
\hline $\operatorname{lmo} 0394$ & - & 9.48 & 176.7 & - & $\sqrt{ }$ & - \\
\hline $\operatorname{lmo} 0433$ & - & - & - & - & - & 2 \\
\hline $\operatorname{lmo} 0434$ & $\sqrt{ }$ & - & $\sqrt{ }$ & - & $\sqrt{ }$ & - \\
\hline $\operatorname{lmo} 0585$ & 5.3 & - & - & 1.6 & $\sqrt{ }$ & - \\
\hline $\operatorname{lmo} 0587$ & - & $\sqrt{ }$ & - & $\sqrt{ }$ & - & $\sqrt{ }$ \\
\hline $\operatorname{lmo} 0723$ & $\sqrt{ }$ & - & $\sqrt{ }$ & - & $\sqrt{ }$ & - \\
\hline $\operatorname{lmo1068}$ & - & - & $\sqrt{ }$ & - & - & - \\
\hline $\operatorname{lmo1076}$ & - & - & $\sqrt{ }$ & - & - & - \\
\hline $\operatorname{lmo1293}$ & 1.9 & - & - & - & - & 3.1 \\
\hline $\operatorname{lmo} 2505$ & 4.6 & - & 11.3 & - & 8.4 & - \\
\hline $\operatorname{lmo} 2558$ & - & - & $\sqrt{ }$ & - & - & - \\
\hline $\operatorname{lmo} 2656$ & - & - & 2.1 & - & - & - \\
\hline $\operatorname{lmo} 2691$ & - & 7.4 & - & - & $\sqrt{ }$ & - \\
\hline $\operatorname{lmo} 2713$ & $\sqrt{ }$ & - & $28,232.2$ & - & $\sqrt{ }$ & - \\
\hline
\end{tabular}

-: Neutral fold-expression; expression not detected in both strains. $\sqrt{ }$ : Not determined; gene expression was not detected in the other strain.

Table 4. Expression fold differences of 15 genes in sessile $\left(30^{\circ} \mathrm{C}\right)$ or planktonic $\left(42{ }^{\circ} \mathrm{C}\right)$ condition compared to their planktonic equivalent at $30^{\circ} \mathrm{C}$.

\begin{tabular}{|c|c|c|c|c|}
\hline \multirow{2}{*}{ Gene Annotation } & \multicolumn{2}{|c|}{ Sessile $\left(30^{\circ} \mathrm{C}\right)$} & \multicolumn{2}{|c|}{ Planktonic $\left(42^{\circ} \mathrm{C}\right)$} \\
\hline & $99-38^{a}$ & CW35 ${ }^{a}$ & $99-38^{a}$ & CW35 ${ }^{\mathrm{a}}$ \\
\hline $\operatorname{lmo} 0202$ & 3.0 & 2.8 & 19.1 & 45.1 \\
\hline $\operatorname{lmo0394}$ & 118.1 & 0.1 & 4.4 & NA \\
\hline $\operatorname{lmo} 0433$ & 0.6 & 1.0 & 0.9 & 2.2 \\
\hline $\operatorname{lmo} 0434$ & 14.2 & NA & 10.4 & NA \\
\hline $\operatorname{lmo} 0585$ & 9.2 & 79.1 & 3.0 & NA \\
\hline $\operatorname{lmo} 0587$ & NA & 74.2 & NA & 7.2 \\
\hline $\operatorname{lmo} 0723$ & 15.9 & NA & 3.3 & NA \\
\hline $\operatorname{lmo} 1068$ & NA & NA & NA & NA \\
\hline $\operatorname{lmo} 1076$ & NA & NA & NA & NA \\
\hline $\operatorname{lmo} 1293$ & 5.4 & 10.0 & 2.2 & 12.8 \\
\hline $\operatorname{lmo} 2505$ & 94.1 & 38.3 & 6.1 & 3.3 \\
\hline $\operatorname{lmo} 2558$ & NA & NA & NA & NA \\
\hline $\operatorname{lmo} 2656$ & 101.5 & 54.7 & 4.4 & 5.2 \\
\hline $\operatorname{lmo} 2691$ & 29.2 & 4.2 & 2.3 & NA \\
\hline $\operatorname{lmo} 2713$ & 44.6 & NA & 7.6 & NA \\
\hline
\end{tabular}

a Expression fold difference; a ratio of treatment/control. NA, not available; expression levels were not detectable. Brackets, group of genes that were overexpressed in both L. monocytogenes 99-38 and CW35 strains when each condition of sessile and $42^{\circ} \mathrm{C}$ was used, as compared to growth at $30^{\circ} \mathrm{C}$. 
Table 5. Amplification efficiency (E) and the percent efficiency (\%E) of each pair of primers (based on L. monocytogenes EGD-e) as used in the quantitation of RTqPCR transcripts. The CW35 and 99-38 genomic DNA was used as template DNA.

\begin{tabular}{|c|c|c|c|c|}
\hline Gene & $\mathrm{CW} 35^{\mathrm{a}}(\mathrm{E})$ & $99-38^{a}(E)$ & CW35 a $(\% E)$ & $99-38^{a}(\% E)$ \\
\hline 16S rRNA & 1.8 & 1.8 & 77.2 & 84.3 \\
\hline $\operatorname{lmo} 0202$ & 1.7 & 1.8 & 72.4 & 81.7 \\
\hline $\operatorname{lmo0394}$ & 1.7 & 1.6 & 66.5 & 61.2 \\
\hline $\operatorname{lmo} 0433$ & 1.9 & 2.0 & 88.0 & 99.0 \\
\hline $\operatorname{lmo} 0434$ & 1.6 & 1.5 & 55.8 & 51.7 \\
\hline $\operatorname{lmo} 0585$ & 1.6 & 1.6 & 64.3 & 57.7 \\
\hline $\operatorname{lmo} 0587$ & 1.7 & 1.9 & 71.4 & 86.6 \\
\hline $\operatorname{lmo} 0723$ & NA & 1.7 & NA & 70.2 \\
\hline $\operatorname{lmo1293}$ & 1.7 & 1.8 & 65.8 & 82.4 \\
\hline $\operatorname{lmo} 1068$ & NA & 1.8 & NA & 77.3 \\
\hline $\operatorname{lmo1076}$ & NA & 1.6 & NA & 59.2 \\
\hline $\operatorname{lmo} 2505$ & 1.7 & 1.6 & 71.4 & 61.4 \\
\hline $\operatorname{lmo} 2558$ & NA & 1.7 & NA & 73.2 \\
\hline $\operatorname{lmo} 2656$ & 1.7 & 1.7 & 72.4 & 69.3 \\
\hline $\operatorname{lmo} 2691$ & 1.7 & 1.9 & 69.2 & 88.4 \\
\hline $\operatorname{lmo} 2713$ & 1.8 & 1.5 & 78.5 & 52.6 \\
\hline
\end{tabular}

a CW35, weakly-adherent phenotype; 99-38, strongly-adherent phenotype. NA, not available due to no signal (Ct).

Table 6. Gene-specific primers used in this study.

\begin{tabular}{|c|c|c|c|}
\hline Gene & Primer Sequence $^{a}$ & Amplicon Size (bp) & Reference \\
\hline 16S rRNA & $\begin{array}{l}\text { F: CGGAGCAACGCCGCGTGTATGAAGAA } \\
\text { R: TATTACCGCGGCTGCTGGCACGTAGTTA }\end{array}$ & 146 & {$[26,42]$ This RT-PCR study } \\
\hline $\operatorname{lmo} 0202$ & $\begin{array}{l}\text { F: ACGGAGATGCAGTGACAAATG } \\
\text { R: TGGATAGGTTAGGCTCGAAATTG }\end{array}$ & 146 & This RT-PCR study \\
\hline $\operatorname{lmo0394}$ & $\begin{array}{l}\text { F: GGAAAGTTGGTTATGTTTCAGG } \\
\text { R: AAACAGCTTGGGCCAGTAG }\end{array}$ & 145 & This RT-PCR study \\
\hline $\operatorname{lmo} 0433$ & $\begin{array}{l}\text { F: TGTTACAAGAACCTACGGCACCAACAA } \\
\text { R: TTGGCGCTATATTGGGCATATAAGGTGATG }\end{array}$ & 145 & This RT-PCR study \\
\hline $\operatorname{lmo} 0434$ & $\begin{array}{l}\text { F: AACCTTTCCTTAGACCGATACG } \\
\text { R: TTGGTAGACCGATAGCTTATTCAC }\end{array}$ & 150 & This RT-PCR study \\
\hline $\operatorname{lmo} 0585$ & $\begin{array}{l}\text { F: TGGAACTTCAATCGTGAGTGTTG } \\
\text { R: AGTGTTGCGCTTCCTGCTG }\end{array}$ & 147 & This RT-PCR study \\
\hline $\operatorname{lmo} 0587$ & $\begin{array}{c}\text { F: ACAATAGCGTCCGTTGTATCTGG } \\
\text { R: TTACTTCAGCCGTTCCACCAC }\end{array}$ & 148 & This RT-PCR study \\
\hline $\operatorname{lmo} 0723 \mathrm{C}$ & $\begin{array}{c}\text { F: TGGTTTCGCAGTCGTAGCCGAAGAA } \\
\text { R: GCTTCGGATTCGGAAAGACCTGTGTTCA }\end{array}$ & 150 & This RT-PCR study \\
\hline $\operatorname{lmo} 1068 \mathrm{~A}$ & $\begin{array}{l}\text { F: TTCTTGGTGGAGATGTAACAACGACGTATT } \\
\text { R: ACTTTCTGGGTTACTCGCACTTACTTCTTT }\end{array}$ & 149 & This RT-PCR study \\
\hline $\operatorname{lmo1076C}$ & $\begin{array}{l}\text { F: CTAATGGTTTATGGTCTGAGGTTCCAGGT } \\
\text { R: ACCGCCTACTTGGAATTGATAGTAAGTTCG }\end{array}$ & 146 & This RT-PCR study \\
\hline $\operatorname{lmo} 1293$ & $\begin{array}{c}\text { F: TTAGAAGAAGGCCGTGAGATGG } \\
\text { R: GCTTCATGTTGAATTGAGTAGCGTAG }\end{array}$ & 146 & This RT-PCR study \\
\hline $\operatorname{lmo} 2505$ & $\begin{array}{l}\text { F: ATCACGTTCACTTACAAGACCAG } \\
\text { R: GAAGATCAAGCAACAGCAATTC }\end{array}$ & 150 & This RT-PCR study \\
\hline $\operatorname{lmo} 2558 \mathrm{C}$ & $\begin{array}{l}\text { F: AGCTCTAACACTCCAACGAGAAGCTACGA } \\
\text { R: TGACGCGACTATATGCAGTGATGGCTTTG }\end{array}$ & 149 & This RT-PCR study \\
\hline $\operatorname{lmo} 2656$ & $\begin{array}{c}\text { F: CACTATGTTCTTGTAAGTTGTGACC } \\
\text { R: AACGTGGCGTATGTACTCG }\end{array}$ & 147 & This RT-PCR study \\
\hline $\operatorname{lmo} 2691$ & $\begin{array}{l}\text { F: AATGCAACAAGCTCTTCTACACC } \\
\text { R: CATGACAGATGCGTACAGGTC }\end{array}$ & 150 & This RT-PCR study \\
\hline $\operatorname{lmo} 2713$ & $\begin{array}{c}\text { F: AAGGCACGTGAGTCAATCC } \\
\text { R: GTAGTAGTGTTAAGTACCTCGGTTCAG }\end{array}$ & 145 & This RT-PCR study \\
\hline 1mo1076B & $\begin{array}{l}\text { F: CGTTATGCAACGGACAACAC } \\
\text { R: ACCATGCCCATCTGCTTTA }\end{array}$ & 150 & This PCR study \\
\hline $\operatorname{lmo1076A}$ & $\begin{array}{l}\text { F: TATGGCTGCTTTAGTCGTGCCTCA } \\
\text { R: TGTCCGTTGCATAACGTCCCTGTA }\end{array}$ & 470 & This PCR study \\
\hline
\end{tabular}


Table 6. Cont.

\begin{tabular}{|c|c|c|c|}
\hline Gene & Primer Sequence $^{a}$ & Amplicon Size (bp) & Reference \\
\hline $\operatorname{lmo1076D}$ & $\begin{array}{c}\text { F: TATGGCTGCTTTAGTCGTGCCTCA } \\
\text { R: ACCGCCTACTTGGAATTGATAGTAAGTTCG }\end{array}$ & 991 & This PCR study \\
\hline $\operatorname{lmo} 2558 B$ & $\begin{array}{c}\text { F: TTA GGC GGAACAACCCATAC } \\
\text { R: AGGCAGTGATTGCTTTATCATATT C }\end{array}$ & 148 & This PCR study \\
\hline $\operatorname{lmo} 2558 \mathrm{~A}$ & $\begin{array}{l}\text { F: TTGCTTCGCGCAACAACAGGATAC } \\
\text { R: ACTGTTCCTTTGCCATCACTGTGC }\end{array}$ & 458 & This PCR study \\
\hline $\operatorname{lmo} 2558 \mathrm{D}$ & $\begin{array}{c}\text { F: TTGCTTCGCGCAACAACAGGATAC } \\
\text { R: TGACGCGACTATATGCAGTGATGGCTTTG }\end{array}$ & 1129 & This PCR study \\
\hline $\operatorname{lmo} 1068 \mathrm{C}$ & $\begin{array}{l}\text { F: TAAGTGCGAGTAACCCAGAAAG } \\
\text { R: CCCGCCGACAGATTTACTT }\end{array}$ & 149 & This PCR study \\
\hline $\operatorname{lmo1068B}$ & $\begin{array}{l}\text { F: CTTGGTGGAGATGTAACAACGACG } \\
\text { R: TGGATCTGGTACGCCTATTTGCGA }\end{array}$ & 438 & This PCR study \\
\hline lmo1068D & $\begin{array}{l}\text { F: TTCTTGGTGGAGATGTAACAACGACGTATT } \\
\text { R: TGGATCTGGTACGCCTATTTGCGA }\end{array}$ & 440 & This PCR study \\
\hline $\operatorname{lmo} 1068 \mathrm{E}$ & $\begin{array}{c}\text { F: CTTGGTGGAGATGTAACAACGACG } \\
\text { R: ACTTTCTGGGTTACTCGCACTTACTTCTTT }\end{array}$ & 147 & This PCR study \\
\hline $\operatorname{lmo} 0723 \mathrm{~A}$ & $\begin{array}{c}\text { F: CGCCGTGCTAATTTCCTTATTC } \\
\text { R:GCCCAGTTCATCTCTACCATT }\end{array}$ & 148 & This PCR study \\
\hline $\operatorname{lmo0723B}$ & $\begin{array}{l}\text { F: TGATGGGCGAACAAATCCAAACCC } \\
\text { R: AACAGCAAGACGTGATTGTTCCGC }\end{array}$ & 416 & This PCR study \\
\hline $\operatorname{lmo} 0723 \mathrm{D}$ & $\begin{array}{c}\text { F: TGATGGGCGAACAAATCCAAACCC } \\
\text { R: GCTTCGGATTCGGAAAGACCTGTGTTCA }\end{array}$ & 505 & This PCR study \\
\hline
\end{tabular}

${ }^{a} \mathrm{~F}$, forward; $\mathrm{R}$, reverse.

Table 7. Functional and virulence information of 15 gene targets.

\begin{tabular}{|c|c|c|c|c|}
\hline Locus Tag & Gene Name [36] & $\begin{array}{l}\text { a Subcellular } \\
\text { Localization }\end{array}$ & Function & Virulence Determinant \\
\hline $\operatorname{lmo} 0202$ & hly & Extracellular [43] & $\begin{array}{l}\text { Listeriolysin, vacuole escape [2]. } \\
\text { Listeria extracellular P60 protein, }\end{array}$ & Yes. Validated [2]. \\
\hline $\operatorname{lmo} 0394$ & - & Extracellular ${ }^{\mathrm{P}}$ & $\begin{array}{l}\text { Iap-like protein, reduced invasion in } \\
\text { mutant [40]. }\end{array}$ & Yes. Not validated [40]. \\
\hline $\operatorname{lmo} 0433$ & inlA & Cell wall [44] & $\begin{array}{l}\text { Internalin, promote adhesion to and } \\
\text { invasion into host intestinal epithelial } \\
\text { cells [2]. Promote adhesion to glass } \\
\text { surface }[22,25] \text {. }\end{array}$ & Yes. Validated $[2,22,25]$. \\
\hline $\operatorname{lmo} 0434$ & $\operatorname{inlB}$ & Cell wall [44] & $\begin{array}{l}\text { Internalin, promote adhesion to and } \\
\text { invasion into host liver cells. Involved } \\
\text { in placental invasion [2] and adhesion } \\
\text { to glass surface }[22,25] \text {. }\end{array}$ & Yes. Validated $[2,22,25]$. \\
\hline $\operatorname{lmo} 0585$ & - & Unknown ${ }^{\mathrm{LP}}$ & Putative secreted protein $[36,37]$. & Not studied. \\
\hline $\operatorname{lmo} 0587$ & - & Unknown ${ }^{\mathrm{LP}}$ & Putative secreted protein $[36,37]$. & Not studied. \\
\hline $\operatorname{lmo} 0723$ & - & Cytoplasm $^{\mathrm{P}}$ & $\begin{array}{l}\text { Methyl-accepting chemotaxis-like } \\
\text { protein }[36,37] \text {. }\end{array}$ & Not studied. \\
\hline $\operatorname{lmo1068}$ & - & Unknown ${ }^{\mathrm{LP}}$ & Unknown function $[36,37]$ & Not studied. \\
\hline $\operatorname{lmo1076}$ & aut & Cell wall [2] & $\begin{array}{l}\text { Promote entry into different } \\
\text { mammalian epithelial cell lines. } \\
\text { Virulence factor }[2,45] \text {. }\end{array}$ & Yes. Validated [45]. \\
\hline $\operatorname{lmo} 1293$ & $g l p \mathrm{D}$ & Cytoplasm $^{\mathrm{P}}$ & $\begin{array}{l}\text { Glycerol-3-phosphate dehydrogenase. } \\
\text { Promote intracellular virulence [46]. } \\
\text { Peptidoglycan lytic protein P45 [47]. }\end{array}$ & Yes. Validated [46]. \\
\hline $\operatorname{lmo} 2505$ & $s p l$ & Cell wall ${ }^{\mathrm{L}}$ & $\begin{array}{l}\text { Iap-like protein, reduced invasion in } \\
\text { mutant [40]. }\end{array}$ & Yes. Not validated [40]. \\
\hline $\operatorname{lmo} 2558$ & ami & Extracellular [2] & $\begin{array}{l}\text { Autolytic amidase, promote adhesion } \\
\text { to mammalian epithelial cells. } \\
\text { Virulence factor }[2,48-50] \text {. }\end{array}$ & Yes. Validated [48-50]. \\
\hline $\operatorname{lmo} 2656$ & $r p s \mathrm{~L}$ & Cell wall ${ }^{\mathrm{L}}$ & Ribosomal protein S12 [36,37]. & Not studied. \\
\hline $\operatorname{lmo} 2691$ & murA & Cell wall ${ }^{\mathrm{L}}$ & $\begin{array}{l}\text { Autolysin, N-acetylmuramidase, } \\
\text { promote cell separation [51]. }\end{array}$ & No. Not validated [41]. \\
\hline $\operatorname{lmo} 2713$ & - & Cell wall [41] & $\begin{array}{l}\text { Unknown, secreted protein with } \\
1 \mathrm{GW} \text { repeat }[36,37] . \text { Internalin-like } \\
\text { protein [41]. }\end{array}$ & No. Validated[39,41]. \\
\hline
\end{tabular}




\section{Discussion}

L. monocytogenes is often detected in food processing plants and its persistence is related to its ability to survive in environments of low temperature, $\mathrm{pH}$, water activity, and the ability to form bioflms. Molecular factors involved in bacterial adherence to various abiotic surfaces has been documented by many groups $[17,18,22,23,52-56]$. Researchers have noted that L. monocytogenes may have multiple surface adhesins (i.e., InlA, InlB, and BapL) that participate in surface adherence $[10,22,25]$. It is also worth noting that the bapL gene is not present in all strongly adherent L. monocytogenes isolates [57].

In the current study, a subset of transcripts from 15 putative surface-associated adhesins overexpressed primarily in the strongly-adherent strain, L. monocytogenes 99-38. This could suggest characterizations of a group of potential adhesins. Listeria strains investigated in this study exhibited more adherence than previous reports $[18,19]$. This could be caused by the high temperature incubation $\left(42{ }^{\circ} \mathrm{C}\right)$ of L. monocytogenes which could result in elevated expression of InlA and InlB surface adhesins, as noted by McGann et al. [21]. Chen et al. [22] confirmed that the adherence of L. monocytogenes cells on glass surfaces may be enhanced by a synergistic activity of these surface proteins and that it may be positively correlated to their expression levels [25]. Gorski et al. [3] noted that adherence of Listeria cells to contact surfaces was independent of flagella, and hence this gene was not analyzed in this study.

When relative gene expression levels were compared between L. monocytogenes CW35 and 99-38 strains, the latter strain possessed more overexpressed genes (Table 3) implicating that the strongly-adherent L. monocytogenes 99-38 expressed more proteins involved in surface adherence. The expression profiles of these genes (i.e., lmo0202, 1mo0434, 1mo1293, 1mo2505, 1mo2656, 1mo2713) were consistent with the protein profiles attained with LC-MS/MS for surface extracts of the 99-38 Listeria cells attached to beads (Table 3A) [24]. Of four abundant proteins detected by LC-MS/MS in surface extracts from planktonic cells of $99-38$ at $30^{\circ} \mathrm{C}$ [24], only one member (lmo0723) correlated with gene expression profiles in this study. These inconsistent profiles could be partly due to the competitive (physical) detection of protein abundancy by LC-MS/MS vs. targeted gene expression studies using real-time RT-PCR as explained by others [58]. Chen et al. [22,25] observed that L. monocytogenes attached more strongly when the transcript levels of inlA/B were abundant. Surprisingly, the CW35 strain demonstrated low adherence on beads even though its relative inlA transcripts were similar to the control (planktonic, $30^{\circ} \mathrm{C}$ ) (Table 2). This observation could suggest the involvement of other adhesins [19].

Chen et al. [25] and Gorski et al. [3] reported that other surface adhesins are considerable and that attachment is temperature-regulated, respectively. Gene expression analysis of other select surface-associated gene products recovered from sessile or planktonic cells grown at $42{ }^{\circ} \mathrm{C}$ revealed that most of the genes tested were differentially up-regulated in one strain or another (Tables 2-4). Of four genes that appear to be upregulated in both strains when held as sessile attached cells at $42{ }^{\circ} \mathrm{C}$ (Table 2), two products (lmo0202, lmo1293) have been implicated in Listeria adaptation of host intracellular stresses whereas the function of $1 \mathrm{mo} 2656$ is unknown $[39,41,46]$. On the other hand, two strain-specific upregulated genes (lmo2691, lmo2713) exhibited intracellular upregulations, as reported by the same groups. Camejo and et al. [2] report of Listeria virulence factors 1 mo0202 (hly), lmo1076 (aut), lmo2558 (ami), and lmo2691 (murA) that are involved in vacuole escape, invasion, adhesion, and autolysis, respectively [2]. However, none of them have been reportedly associated with Listeria adhesion to abiotic surfaces.

Chen et al. [2,22] reported that both surface-associated InlA and InlB proteins of L. monocytogenes promote attachment equally well to mammalian epithelial cells as well as abiotic surface adherence. Various groups have revealed that attached cells of L. monocytogenes to different substrate surfaces can be easily removed with protein denaturants $[18,59]$ suggesting the proteinaceous nature of adherence factors. A mammalian epithelial cell adhesin, Ami, is known to have high levels of amino acid sequence homology to Staphylococcus aureus major autolysin (attE) that contributes to cell adherence to polystyrene, hence suggesting that this gene may also be involved in abiotic attachment $[23,48-50,60]$. 
The genes used in this study were primarily surface-associated proteins (10), unknown (3), and cytoplasmic related (2) (Table 7). The detection of cytoplasmic-surface related proteins by LC-MS/MS analysis of surface extracts of L. monocytogenes suggests the involvement of moonlighting proteins that have multiple functions and locations [24,61-66]. Cytoplasmic protein lmo1293 shows considerable involvement in Listeria adherence as indicated by overexpressed levels of mRNA under all conditions and strains tested (Table 4). The data presented herein suggests that these genes are worthy of further investigations for potential roles as surface adhesins. Information on new adhesins may benefit food processors through improved sanitation regimens were enzyme-based sanitizers are increasingly being used to combat Listeria biofilms in food processing facilities to ensure RTE food products safe from contamination with $L$. monocytogenes as a public health concern.

\section{Materials and Methods}

\subsection{L. monocytogenes Strains}

Initial adherence assays were carried out with eight strains of L. monocytogenes (weakly adherent strains: CW34, CW35, CW52, SM3; strongly adherent strains: CW50, CW62, CW77, JAG167, 99-38). Two adherent forms of L. monocytogenes (CW35, 99-38) were chosen for further analysis (real-time RT-PCR). All 'CW' strains originated from RTE retail frankfurters whereas strains 99-38 and SM3 were isolated from retail ground beef while JAG167 was isolated from an RTE meat processing plant $[9,17,19]$. The bacterial strains were cultured by transferring $100 \mu \mathrm{L}$ of thawed frozen culture suspension into $9 \mathrm{~mL}$ of brain heart infusion (BHI) broth (Difco; Becton-Dickinson, Franklin Lakes, NJ, USA), incubated overnight (18 to $24 \mathrm{~h}$ ) at $30^{\circ} \mathrm{C}$ and subcultured twice before experimental tests. Frozen culture stocks were prepared from $9 \mathrm{~mL}$ of overnight culture, centrifuged, resuspended in $2 \mathrm{~mL}$ of sterile BHI broth (containing $10 \%$ glycerol) and stored at $-76^{\circ} \mathrm{C}$.

\subsection{Fluorescent Microplate Adherence Assay}

An adherence ability was characterized as described by Gamble and Muriana $[18,19]$. A consistent positive correlation between cell adhesion abilities and the viable count has been validated by many groups $[17,19,20]$. Briefly, each Listeria strain was cultured at $30^{\circ} \mathrm{C}$ and diluted 5-log in fresh BHI broth, and $200 \mu \mathrm{L}$ was transferred into designated wells of a sterile 96 -well black polystyrene untreated microplates (Nunc, Roskilde, Denmark) with a clear lid, wrapped with Parafilm (Alcan Packaging, Neenah, WI, USA), and incubated at $30{ }^{\circ} \mathrm{C}$ for $24 \mathrm{~h}$. Subsequently, the plate was washed three times with Tris buffer ( $\mathrm{pH} 7.4,0.05 \mathrm{M}$ ) in a Biotec Elx405 Magna automated plate washer (Ipswich, Suffolk, UK) to remove loosely adhered cells, and the plate washer was afterwards sanitized with $200 \mathrm{ppm}$ of sodium hypochlorite ( $\mathrm{pH}$ 6.5) after each use. The cells were subjected to another cycle of incubation in fresh BHI broth $(200 \mu \mathrm{L})$, which was followed by washing. After the final incubation and washing, the cells were suspended in $200 \mu \mathrm{L}$ of 5,6-carboxy-fluorescein diacetate (5,6-CFDA; Invitrogen, Carlsbad, CA, USA) fluorescent substrate solution, incubated at $30^{\circ} \mathrm{C}$ for $15 \mathrm{~min}$, washed (as mentioned above), and suspended with the same Tris buffer $(200 \mu \mathrm{L})$. The plate was then read from above in a Tecan GENios fluorescent plate reader (Phoenix Research Products, Hayward, CA, USA) using a fixed signal gain of $75 \%$ (unless otherwise specified) with an excitation wavelength of $485 \mathrm{~nm}$ and a detection wavelength of $535 \mathrm{~nm}$.

\subsection{Extraction, Purification and Evaluation of Chromosomal DNA}

Chromosomal DNA was extracted using the glass bead collision method of Coton and Coton with minor modifications [35]. Briefly, pelleted overnight cells of L. monocytogenes were resuspended with sterile DI water and spun down twice before subjected to bead collision in Tris buffer $(10 \mathrm{mM}$, pH 8) to shear the cells and release cytosolic components. Chromosomal DNA and cell debris were spun to form supernatant and pellet, respectively. Supernatant containing DNA was aspirated into 
sterile Eppendorf tubes and stored at $-20^{\circ} \mathrm{C}$. The quality of DNA was verified using a NanoDrop ${ }^{\circledR}$ ND-1000 spectrophotometer (Thermo Scientific, South San Francisco, CA, USA) and PCR.

\subsection{PCR, DNA Agarose Gel Electrophoresis and Sequencing Analysis}

PCR mixtures for amplification of genes were prepared according to the manufacturer's directions for GoTaq Flexi DNA Polymerase (Promega, Madison, WI, USA). Briefly, each amplification contained $0.2 \mathrm{mM}$ deoxynucleoside triphosphate mix (Fisher Scientific, Fair Lawn, NJ, USA), $1.5 \mathrm{mM} \mathrm{MgCl} 2$ (Promega), 1.25 U GoTaq polymerase (Promega), and $0.4 \mu \mathrm{M}$ of primers (IDT, Coralville, IA, USA) (Table 6). The reaction conditions were programmed as follows: initial denaturation of $5 \mathrm{~min}$ at $95{ }^{\circ} \mathrm{C}$, followed by 40 cycles of 1 min denaturation at $95^{\circ} \mathrm{C}$, annealing for $40 \mathrm{~s}$ (primer-dependent temperature; Table 1), extension for $60 \mathrm{~s}$ at $72{ }^{\circ} \mathrm{C}$ (Table 1), and a final extension cycle of $72{ }^{\circ} \mathrm{C}$ for 10 min before holding at $4{ }^{\circ} \mathrm{C}$ in a PTC-200 thermal cycler (MJ Research, Bio-Rad, Hercules, CA, USA). All nucleotide oligomers used in this study were generated from the specific DNA sequences of the L. monocytogenes type strain EGDe (NCBI) type strain by Integrated DNA technology (IDT).

PCR products were examined by agarose gel electrophoresis and purified using a Wizard SV Gel and PCR clean-up kit (Promega), and submitted to the Department of Biochemistry and Molecular Biology Recombinant DNA and Protein core facility (Oklahoma State University, Stillwater, OK) for sequence identification with a ABI 3730 DNA analyzer.

\subsection{Total RNA Extraction, Purification, cDNA Synthesis, Evaluation, and Real-Time Reverse Transcription PCR}

\subsubsection{Cells Attached to Glass Beads}

Strains of L. monocytogenes were grown in screw cap bottles containing glass beads ( $5 \mathrm{~mm}, 80 \mathrm{~g}$ ) immersed in BHI broth for $18 \mathrm{~h}$ at $30^{\circ} \mathrm{C}$ or $42^{\circ} \mathrm{C}$. Each day (for 6 days), bottles of L. monocytogenes incubated with glass beads were decanted, washed $(1 \times$ PBS) on a rotating machine (10 min per wash), and followed by another six daily cycles of incubation in fresh BHI prior to cell harvesting for total RNA extraction. At the end of incubation and washing, attached cells were harvested by gentle shaking with a reciprocating vortex shaker (MRC, Cincinnati, OH, USA) using RNAzol®RT solution and transferred into sterile Eppendorf tubes.

\subsubsection{Planktonic Cells}

Pelleted cells of various strains of L. monocytogenes in sterile Eppendorf tubes were prepared from $1 \mathrm{~mL}$ of overnight cultures in BHI broth at $30^{\circ} \mathrm{C}$ or $42{ }^{\circ} \mathrm{C}$, and washed 3 times by suspension with $1 \times$ PBS prior to total RNA extraction.

Both washed adhered and pelleted planktonic cells were lysed by repeated pipetting in $1 \mathrm{~mL}$ of RNAzol ${ }^{\circledR}$ RT solution (MRC) for total RNA extraction, as instructed by manufacturer. Residual DNA was removed with gDNA wipe-out reagent included in the QIAGEN QuantiTect Reverse Transcription Kit (QIAGEN, Valencia, CA, USA) as instructed by the manufacturer. A $2.8 \mu \mathrm{L}$ reaction mixture of genomic DNA (gDNA) wipe-out solution contained $0.15 \mu \mathrm{g}$ of total RNA, $0.4 \mu \mathrm{L}$ of gDNA Wipeout Buffer $(7 \times)$, and RNase-free water. This reaction mixture was subsequently incubated in a water bath at $42{ }^{\circ} \mathrm{C}$ for $2 \mathrm{~min}$. The degradation of DNA was verified by PCR amplification of one of the genes to be assayed (lmo0202, hly) using RNA extract containing $1 \mu \mathrm{g}$ of RNA as the potential PCR template. RNA purity and integrity were verified with UV absorbance ratio $(260 / 280)$ and denaturing agarose gel (1.5\%) analysis, respectively. The RNA concentration was determined with a NanoDrop ND-1000 spectrophotometer (NanoDrop Products, Wilmington, DE, USA) measured at $260 \mathrm{~nm}$. RNA samples were kept at $-80^{\circ} \mathrm{C}$ for storage.

\subsubsection{Synthesis of cDNA}

Synthesis of cDNA was performed using the same Qiagen kit above (QuantiTect Reverse Transcription Kit) as described by manufacturer. A $4 \mu \mathrm{L}$ volume of cDNA synthesis buffer contained 
$0.2 \mu \mathrm{L}$ Quantiscript Reverse Transcriptase, $0.8 \mu \mathrm{L}$ of Quantiscript RT Buffer $(5 \times), 0.2 \mu \mathrm{L}$ of RT Primer Mix, and approximate $2.8 \mu \mathrm{L}$ of the remaining reaction product. The reaction was then carried out at $42{ }^{\circ} \mathrm{C}$ for $30 \mathrm{~min}$ and finally at $95^{\circ} \mathrm{C}$ for $3 \mathrm{~min}$ to inactivate reverse transcriptase enzyme. The formation of cDNA in the synthesis buffer was verified by PCR amplification of the hly gene with $0.5 \mu \mathrm{L}$ of cDNA synthesis product as the template and agarose gel electrophoresis. The concentration was determined with a NanoDrop ND-1000 spectrophotometer measured at $260 \mathrm{~nm}$. Samples of cDNA were stored at $-20^{\circ} \mathrm{C}$.

\subsubsection{Real-Time Reverse Transcriptase Quantitative PCR}

Real-time reverse transcriptase quantitative PCR (real-time RT-qPCR) of first-strand cDNA was prepared using the QuantiTect SYBR Green PCR Kit (QIAGEN) and performed in a MyiQ Real-Time PCR Detection System (Bio-Rad) as described by Xiao et al. [67]. Briefly, $10 \mu \mathrm{L}$ of PCR reaction mixtures contained $5 \mu \mathrm{L}$ of QuantiTect SYBR Green PCR Master Mix, $0.2 \mu \mathrm{g}$ of the first-strand cDNA, and $0.3 \mu \mathrm{M}$ of gene-specific primers as listed in Table 2. The real-time PCR reactions were carried out in 96-microwell plates (Axygen) for production of $\sim 150 \mathrm{bp}$ amplicons: initial denaturation at $95^{\circ} \mathrm{C}$ for $10 \mathrm{~min}$, and 40 cycles of denaturation at $94^{\circ} \mathrm{C}$ for $15 \mathrm{~s}$, annealing at $50-60{ }^{\circ} \mathrm{C}$ (based on individual PCR thermal gradient analysis) for $20 \mathrm{~s}$, and extension at $72{ }^{\circ} \mathrm{C}$ for $1 \mathrm{~min}$. The specificity of PCR amplifications were verified by melting curve analysis and agarose gel electrophoresis of real-time PCR products (between $50-60^{\circ} \mathrm{C}$ and $95^{\circ} \mathrm{C}$ ). The relative expression ratios of specific genes of one strain of L. monocytogenes to the other were measured based on the crossing point and amplification efficiency (E) values normalized to a reference gene (16S rRNA). Expression ratio analysis (1) used the following relative quantification method, delta $\mathrm{Ct}[30,33,34]$ as derived from Pfaffl's and Livak's $2^{-\Delta \Delta C T}$ method for relative quantification of gene expression to accommodate different PCR amplification efficiencies of a gene (2). PCR amplification efficiency was obtained using the formula (2) as described [30,68]. The amplification efficiency of primer sets can be found in Table 5 .

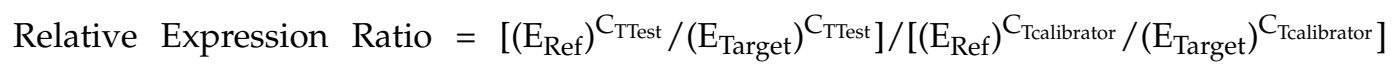

$$
\begin{aligned}
& \text { Amplification Efficiency }=\mathrm{E}=\left\{\left[10^{(-1 / \text { slope })}\right]-1\right\} \times 100
\end{aligned}
$$

Identities of a subset of PCR products (i.e., lmo0202, lmo0723, lmo1293, lmo2505, 1mo2656, lmo1076 amplicons) were verified by DNA sequencing at the OSU core facility.

\subsection{Statistical Significant Measurement}

Comparison studies (attachment strength or expression values) either within each strain or between strains yielded pairs of mean bars with respective standard deviation (error bars). Student's t-test in Sigmaplot 13 was used to analyze each pair of means for determination of significant difference. Statistically significant differences between means compared were called at $P<0.05$.

\section{Conclusion}

Adherence of L. monocytogenes to abiotic surfaces is a serious problem impacting sanitation in food manufacturing industry affecting persistence of the organism that may result in contamination of RTE products and human listeriosis transmitted through ingestion of contaminated foods. The ability to adhere promotes initial attachment that can lead to more fully-developed biofilms that are difficult to remove and can resist sanitization regimens. Attachment can be attributed to a group of genes encoding surface adhesins. The current relative mRNA expression study suggested new suspect adhesins based on observations with strain-specific and inducible gene expression profiles, supported by current literature on the function of closely related genes. The genes that were examined encode 5 functionally unknown proteins (lmo0723, lmo0585, lmo0587, 1mo1068, lmo2656), 4 virulence proteins (lmo0202, lmo1076, lmo1293, lmo2558), 2 that were similar to other virulence proteins (i.e., Iap: lmo0394, 
$1 \mathrm{mo} 2505)$ and 2 that were not associated with virulence (lmo2691, 1mlo2713). These additional roles as potential adhesins would further qualify them as moonlighting proteins. Knowledge of different conditions that are capable of regulating a group of adhesin genes and understanding the mechanisms leading to Listeria attachment, may help prevent facility contamination by manipulating physical and biological conditions. These results imply that more than one surface protein may regulate the adherence property (jointly or independently) and the role of overexpressed genes in Listeria adherence should be further investigated as to whether they contribute to persistent biofilms.

Acknowledgments: Funding support was provided in part by the Oklahoma Experiment Station, the Robert M. Kerr Food and Ag Products Center, USDA HATCH Project \#OKL02885, USDA-CSREES 2008-34476-19161 and 2009-34476-20073, and the Advance Foods-Gilliland Professorship in Microbial Food Safety.

Author Contributions: Hung King Tiong performed the work during the course of his PhD dissertation studies at Oklahoma State University (Dept. of Animal Science) and wrote the initial rough draft of the paper. Peter M. Muriana was Tiong's PhD research advisor, the PI on the grants that funded the work, and final editor of the manuscript that was submitted.

Conflicts of Interest: The authors declare no conflict of interest.

\section{References}

1. Sewell, D.; Allen, S.C.; Phillips, C.A. Oxygen limitation induces acid tolerance and impacts simulated gastro-intestinal transit in Listeria monocytogenes J0161. Gut. Path. 2015, 7, 1-5. [CrossRef] [PubMed]

2. Camejo, A.; Carvalho, F.; Reis, O.; Leitao, E.; Sousa, S.; Cabanes, D. The arsenal of virulence factors deployed by Listeria monocytogenes to promote its cell infection cycle. Virulence 2011, 2, 379-394. [CrossRef] [PubMed]

3. Gorski, L.; Palumbo, J.D.; Mandrell, R.E. Attachment of Listeria monocytogenes to radish tissue is dependent upon temperature and flagellar motility. Appl. Environ. Microbiol. 2003, 69, 258-266. [CrossRef] [PubMed]

4. Mateus, T.; Silva, J.; Maia, R.L.; Teixeira, P. Listeriosis during Pregnancy: A Public Health Concern. ISRN Obstet. Gynecol. 2013, 2013, 851712. [CrossRef] [PubMed]

5. Lecuit, M. Understanding how Listeria monocytogenes targets and crosses host barriers. Clin. Microbiol. Infect. 2005, 11, 430-436. [CrossRef] [PubMed]

6. Garcia-Montero, M.; Rodriguez-Garcia, J.L.; Calvo, P.; Gonzalez, J.M.; Fernandez-Garrido, M.; Loza, E.; Serrano, M. Pneumonia caused by Listeria monocytogenes. Respiration 1995, 62, 107-109. [CrossRef] [PubMed]

7. Holland, S.; Alfonso, E.; Gelender, H.; Heidemann, D.; Mendelsohn, A.; Ullman, S.; Miller, D. Corneal ulcer due to Listeria monocytogenes. Cornea 1987, 6, 144-146. [CrossRef] [PubMed]

8. Dalton, C.B.; Austin, C.C.; Sobel, J.; Hayes, P.S.; Bibb, W.F.; Graves, L.M.; Swaminathan, B.; Proctor, M.E.; Griffin, P.M. An outbreak of gastroenteritis and fever due to Listeria monocytogenes in milk. N. Engl. J. Med. 1997, 336, 100-105. [CrossRef] [PubMed]

9. Wang, C.H.; Muriana, P.M. Incidence of Listeria monocytogenes in packages of retail franks. J. Food Prot. 1994, 57, 382-386.

10. Jordan, S.J.; Perni, S.; Glenn, S.; Fernandes, I.; Barbosa, M.; Sol, M.; Tenreiro, R.P.; Chambel, L.; Barata, B.; Zilhao, I.; et al. Listeria monocytogenes biofilm-associated protein (BapL) may contribute to surface attachment of L. monocytogenes but is absent from many field isolates. Appl. Environ. Microbiol. 2008, 74, 5451-5456. [CrossRef] [PubMed]

11. Ruhland, G.J.; Hellwig, M.; Wanner, G.; Fiedler, F. Cell-surface location of Listeria-specific protein p60-detection of Listeria cells by indirect immunofluorescence. J. Gen. Microbiol. 1993, 139, 609-616. [CrossRef] [PubMed]

12. Farber, J.M.; Peterkin, P.I. Listeria monocytogenes, a food-borne pathogen. Microbiol. Rev. 1991, 55, 476-511. [PubMed]

13. Frank, J.F.; Koffi, R.A. Surface-adherent growth of Listeria monocytogenes is associated with increased resistance to surfactant sanitizers and heat. J. Food. Prot. 1990, 53, 550-554.

14. Borucki, M.K.; Peppin, J.D.; White, D.; Loge, F.; Call, D.R. Variation in biofilm formation among strains of Listeria monocytogenes. Appl. Environ. Microbiol. 2003, 69, 7336-7342. [CrossRef] [PubMed]

15. Shin Ho, L.; Frank, J.F. Inactivation of surface-adherent Listeria monocytogenes hypochlorite and heat. J. Food Prot. 1991, 54, 4-11. 
16. Kim, T.; Silva, J.L. Quantification of attachment strength of selected foodborne pathogens by the blot succession method. J. Rapid Meth. Automat. Microbiol. 2005, 13, 127-133. [CrossRef]

17. Kushwaha, K.; Muriana, P.M. Adherence characteristics of Listeria strains isolated from three ready-to-eat meat processing plants. J. Food Prot. 2009, 72, 2125-2131. [PubMed]

18. Gamble, R.; Muriana, P.M. Microplate fluorescence assay for measurement of the ability of strains of Listeria monocytogenes from meat and meat-processing plants to adhere to abiotic surfaces. Appl. Environ. Microbiol. 2007, 73, 5235-5244. [CrossRef] [PubMed]

19. Kushwaha, K.; Muriana, P.M. Comparison of invasiveness among surface-adherent variants of Listeria monocytogenes in Caco-2 cell culture assays. Int. J. Food Microbiol. 2010, 138, 166-171. [CrossRef] [PubMed]

20. Kushwaha, K.; Muriana, P.M. Analysis of tissue invasiveness of adherent strains of Listeria monocytogenes by in vivo mouse assay. Int. J. Food. Microbiol. 2010, 141, 104-109. [CrossRef] [PubMed]

21. McGann, P.; Ivanek, R.; Wiedmann, M.; Boor, K.J. Temperature-dependent expression of Listeria monocytogenes internalin and internalin-like genes suggests functional diversity of these proteins among the listeriae. Appl. Environ. Microbiol. 2007, 73, 2806-2814. [CrossRef] [PubMed]

22. Chen, B.Y.; Kim, T.J.; Jung, Y.S.; Silva, J.L. Attachment strength of Listeria monocytogenes and its internalin-negative mutants. Food Biophys. 2008, 3, 329-332. [CrossRef]

23. Heilmann, C.; Hussain, M.; Peters, G.; Gotz, F. Evidence for autolysin-mediated primary attachment of Staphylococcus epidermidis to a polystyrene surface. Mol. Microbiol. 1997, 24, 1013-1024. [CrossRef]

24. Tiong, H.; Hartson, S.; Muriana, P. Comparison of Surface Proteomes of Adherence Variants of Listeria Monocytogenes Using LC-MS/MS for Identification of Potential Surface Adhesins. Pathogens 2016, 5, 40. [CrossRef] [PubMed]

25. Chen, B.-Y.; Kim, T.-J.; Silva, J.L.; Jung, Y.-S. Positive correlation between the expression of inlA and inlB genes of Listeria monocytogenes and its attachment strength on glass surface. Food Biophys. 2009, 4, 304-311. [CrossRef]

26. Tasara, T.; Stephan, R. Evaluation of housekeeping genes in Listeria monocytogenes as potential internal control references for normalizing mRNA expression levels in stress adaptation models using real-time PCR. FEMS Microbiol. Lett. 2007, 269, 265-272. [CrossRef] [PubMed]

27. Morange, M.; Hevin, B.; Fauve, R.M. Differential heat-shock protein synthesis and response to stress in three avirulent and virulent Listeria species. Res. Immunol. 1993, 144, 667-677. [CrossRef]

28. Ramnath, M.; Rechinger, K.B.; Jänsch, L.; Hastings, J.W.; Knøchel, S.; Gravesen, A. Development of a Listeria monocytogenes EGDe partial proteome reference map and comparison with the protein profiles of food isolates. Appl. Environ. Microbiol. 2003, 69, 3368-3376. [CrossRef] [PubMed]

29. Hong, Y.; Brown, D.G. Variation in bacterial ATP level and proton motive force due to adhesion to a solid surface. Appl. Environ. Microbiol. 2009, 75, 2346-2353. [CrossRef] [PubMed]

30. Pfaffl, M.W. A new mathematical model for relative quantification in real-time RT-PCR. Nucleic Acids Res. 2001, 29, e45. [CrossRef] [PubMed]

31. Nightingale, K.K.; Milillo, S.R.; Ivy, R.A.; Ho, A.J.; Oliver, H.F.; Wiedmann, M. Listeria monocytogenes F2365 carries several authentic mutations potentially leading to truncated gene products, including inlB, and demonstrates atypical phenotypic characteristics. J. Food. Prot. 2007, 70, 482-488. [PubMed]

32. Werbrouck, H.; Grijspeerdt, K.; Botteldoorn, N.; van Pamel, E.; Rijpens, N.; van Damme, J.; Uyttendaele, M.; Herman, L.; van Coillie, E. Differential inlA and inlB expression and interaction with human intestinal and liver cells by Listeria monocytogenes strains of different origins. Appl. Environ. Microbiol. 2006, 72, 3862-3871. [CrossRef] [PubMed]

33. Souaze, F.; Ntodou-Thome, A.; Tran, C.Y.; Rostene, W.; Forgez, P. Quantitative RT-PCR: limits and accuracy. Biotechniques 1996, 21, 280-285. [PubMed]

34. Livak, K.J.; Schmittgen, T.D. Analysis of relative gene expression data using real-time quantitative PCR and the 2(-Delta Delta C(T)) Method. Methods 2001, 25, 402-408. [CrossRef] [PubMed]

35. Coton, E.; Coton, M. Multiplex PCR for colony direct detection of Gram-positive histamine- and tyramine-producing bacteria. J. Microbiol. Methods 2005, 63, 296-304. [CrossRef] [PubMed]

36. Dieterich, G.; Karst, U.; Fischer, E.; Wehland, J.; Jansch, L. LEGER: Knowledge database and visualization tool for comparative genomics of pathogenic and non-pathogenic Listeria species. Nucleic Acids Res. 2006, 34, D402-D406. [CrossRef] [PubMed] 
37. Moszer, I.; Glaser, P.; Danchin, A. Subtilist: A relational database for the Bacillus subtilis genome. Microbiology 1995, 141, 261-268. [CrossRef] [PubMed]

38. Tiong, H.K.; Hartson, S.; Muriana, P.M. Comparison of five methods for direct extraction of surface proteins from Listeria monocytogenes for proteomic analysis by orbitrap mass spectrometry. J. Microbiol. Meth. 2015, 110, 54-60. [CrossRef] [PubMed]

39. Camejo, A.; Buchrieser, C.; Couvé, E.; Carvalho, F.; Reis, O.; Ferreira, P.; Sousa, S.; Cossart, P.; Cabanes, D. In vivo transcriptional profiling of Listeria monocytogenes and mutagenesis identify new virulence factors involved in infection. PLoS Pathog. 2009, 5, e1000449. [CrossRef] [PubMed]

40. Pilgrim, S.; Kolb-Maurer, A.; Gentschev, I.; Goebel, W.; Kuhn, M. Deletion of the gene encoding p60 in Listeria monocytogenes leads to abnormal cell division and loss of actin-based motility. Infect. Immun. 2003, 71, 3473-3484. [CrossRef] [PubMed]

41. Chatterjee, S.S.; Hossain, H.; Otten, S.; Kuenne, C.; Kuchmina, K.; Machata, S.; Domann, E.; Chakraborty, T.; Hain, T. Intracellular gene expression profile of Listeria monocytogenes. Infect. Immun. 2006, 74, 1323-1338. [CrossRef] [PubMed]

42. Doumith, M.; Cazalet, C.; Simoes, N.; Frangeul, L.; Jacquet, C.; Kunst, F.; Martin, P.; Cossart, P.; Glaser, P.; Buchrieser, C. New aspects regarding evolution and virulence of Listeria monocytogenes revealed by comparative genomics and DNA arrays. Infect. Immun. 2004, 72, 1072-1083. [CrossRef] [PubMed]

43. Pizarro-Cerda, J.; Kuhbacher, A.; Cossart, P. Entry of Listeria monocytogenes in mammalian epithelial cells: An updated view. Cold Spring Harb. Perspect. Med. 2012, 2. [CrossRef] [PubMed]

44. Grundler, T.; Quednau, N.; Stump, C.; Orian-Rousseau, V.; Ishikawa, H.; Wolburg, H.; Schroten, H.; Tenenbaum, T.; Schwerk, C. The surface proteins InlA and InlB are interdependently required for polar basolateral invasion by Listeria monocytogenes in a human model of the blood-cerebrospinal fluid barrier. Microbes Infect. 2013, 15, 291-301. [CrossRef] [PubMed]

45. Cabanes, D.; Dussurget, O.; Dehoux, P.; Cossart, P. Auto, a surface associated autolysin of Listeria monocytogenes required for entry into eukaryotic cells and virulence. Mol. Microbiol. 2004, 51, 1601-1614. [CrossRef] [PubMed]

46. Joseph, B.; Przybilla, K.; Stuhler, C.; Schauer, K.; Slaghuis, J.; Fuchs, T.M.; Goebel, W. Identification of Listeria monocytogenes genes contributing to intracellular replication by expression profiling and mutant screening. J. Bacteriol. 2006, 188, 556-568. [CrossRef] [PubMed]

47. Schubert, K.; Bichlmaier, A.M.; Mager, E.; Wolff, K.; Ruhland, G.; Fiedler, F. P45, an extracellular 45 kDa protein of Listeria monocytogenes with similarity to protein p60 and exhibiting peptidoglycan lytic activity. Arch. Microbiol. 2000, 173, 21-28. [CrossRef] [PubMed]

48. Milohanic, E.; Jonquieres, R.; Cossart, P.; Berche, P.; Gaillard, J.L. The autolysin Ami contributes to the adhesion of Listeria monocytogenes to eukaryotic cells via its cell wall anchor. Mol. Microbiol. 2001, 39, 1212-1224. [CrossRef] [PubMed]

49. Milohanic, E.; Jonquieres, R.; Glaser, P.; Dehoux, P.; Jacquet, C.; Berche, P.; Cossart, P.; Gaillard, J.L. Sequence and binding activity of the autolysin-adhesin Ami from epidemic Listeria monocytogenes $4 \mathrm{~b}$. Infect. Immun. 2004, 72, 4401-4409. [CrossRef] [PubMed]

50. Milohanic, E.; Pron, B.; Berche, P.; Gaillard, J.L. Identification of new loci involved in adhesion of Listeria monocytogenes to eukaryotic cells. European Listeria Genome Consortium. Microbiology 2000, 146, 731-739. [CrossRef] [PubMed]

51. Carroll, S.A.; Hain, T.; Technow, U.; Darji, A.; Pashalidis, P.; Joseph, S.W.; Chakraborty, T. Identification and characterization of a peptidoglycan hydrolase, MurA, of Listeria monocytogenes, a muramidase needed for cell separation. J. Bacteriol. 2003, 185, 6801-6808. [CrossRef] [PubMed]

52. Tran, V.B.; Fleiszig, S.M.; Evans, D.J.; Radke, C.J. Dynamics of flagellum- and pilus-mediated association of Pseudomonas aeruginosa with contact lens surfaces. Appl. Environ. Microbiol. 2011, 77, 3644-3652. [CrossRef] [PubMed]

53. Hinsa, S.M.; Espinosa-Urgel, M.; Ramos, J.L.; O'Toole, G.A. Transition from reversible to irreversible attachment during biofilm formation by Pseudomonas fluorescens WCS365 requires an ABC transporter and a large secreted protein. Mol. Microbiol. 2003, 49, 905-918. [CrossRef] [PubMed]

54. Espinosa-Urgel, M.; Salido, A.; Ramos, J.L. Genetic analysis of functions involved in adhesion of Pseudomonas putida to seeds. J. Bacteriol. 2000, 182, 2363-2369. [CrossRef] [PubMed] 
55. Cucarella, C.; Tormo, M.A.; Knecht, E.; Amorena, B.; Lasa, I.; Foster, T.J.; Penades, J.R. Expression of the biofilm-associated protein interferes with host protein receptors of Staphylococcus aureus and alters the infective process. Infect. Immun. 2002, 70, 3180-3186. [CrossRef] [PubMed]

56. Heilmann, C. Adhesion mechanisms of staphylococci. Adv. Exp. Med. Biol. 2011, 715, 105-123. [PubMed]

57. Renier, S.; Hébraud, M.; Desvaux, M. Molecular biology of surface colonization by Listeria monocytogenes: an additional facet of an opportunistic Gram-positive foodborne pathogen. Environ. Microbiol. 2011, 13, 835-850. [CrossRef] [PubMed]

58. Qian, W.-J.; Kaleta, D.T.; Petritis, B.O.; Jiang, H.; Liu, T.; Zhang, X.; Mottaz, H.M.; Varnum, S.M.; Camp, D.G.; Huang, L.; et al. Enhanced detection of low abundance human plasma proteins using a tandem IgY12-supermix immunoaffinity separation strategy. Molec. Cell. Proteom. 2008, 7, 1963-1973. [CrossRef] [PubMed]

59. Eginton, P.J.; Holah, J.; Allison, D.G.; Handley, P.S.; Gilbert, P. Changes in the strength of attachment of micro-organisms to surfaces following treatment with disinfectants and cleansing agents. Lett. Appl. Microbiol. 1998, 27, 101-105. [CrossRef] [PubMed]

60. McLaughlan, A.M.; Foster, S.J. Molecular characterization of an autolytic amidase of Listeria monocytogenes EGD. Microbiology 1998, 144, 1359-1367. [CrossRef] [PubMed]

61. Bergmann, S.; Rohde, M.; Chhatwal, G.S.; Hammerschmidt, S. $\alpha$-Enolase of Streptococcus pneumoniae is a plasmin(ogen)-binding protein displayed on the bacterial cell surface. Mol. Microbiol. 2001, 40, 1273-1287. [CrossRef]

62. Wilkins, J.C.; Beighton, D.; Homer, K.A. Effect of acidic $\mathrm{pH}$ on expression of surface-associated proteins of Streptococcus oralis. Appl. Environ. Microbiol. 2003, 69, 5290-5296. [CrossRef] [PubMed]

63. Jagadeesan, B.; Koo, O.K.; Kim, K.-P.; Burkholder, K.M.; Mishra, K.K.; Aroonnual, A.; Bhunia, A.K. LAP, an alcohol acetaldehyde dehydrogenase enzyme in Listeria, promotes bacterial adhesion to enterocyte-like Caco-2 cells only in pathogenic species. Microbiology 2010, 156, 2782-2795. [CrossRef] [PubMed]

64. Jeffery, C.J. Moonlighting proteins. Trends Biochem. Sci. 1999, 24, 8-11. [CrossRef]

65. Jeffery, C.J. Protein species and moonlighting proteins: Very small changes in a protein's covalent structure can change its biochemical function. J. Proteom. 2015. [CrossRef] [PubMed]

66. Wang, G.; Xia, Y.; Cui, J.; Gu, Z.; Song, Y.; Chen, Y.Q.; Chen, H.; Zhang, H.; Chen, W. The roles of moonlighting proteins in bacteria. Curr. Issues Mol. Biol. 2014, 16, 15-22. [PubMed]

67. Xiao, Y.; Cai, Y.; Bommineni, Y.R.; Fernando, S.C.; Prakash, O.; Gilliland, S.E.; Zhang, G. Identification and functional characterization of three chicken cathelicidins with potent antimicrobial activity. J. Biol. Chem. 2006, 281, 2858-2867. [CrossRef] [PubMed]

68. Rasmussen, R. Quantification on the LightCycler. In Rapid Cycle Real-Time PCR: Methods and Applications; Meuer, S., Wittwer, C., Nakagawara, K.-I., Eds.; Springer: Berlin/Heidelberg, Germany, 2001; pp. 21-34.

(C) 2016 by the authors; licensee MDPI, Basel, Switzerland. This article is an open access article distributed under the terms and conditions of the Creative Commons Attribution (CC-BY) license (http://creativecommons.org/licenses/by/4.0/). 